Brit. J. vener. Dis. (1963), 39, 118.

\title{
INVESTIGATION OF NON-GONOCOCCAL URETHRITIS BY ANAEROBIC CULTURE*
}

BY

\author{
A. I. MORRISON \\ Royal Hospital, Sheffield
}

Since 1951, when the numbers of cases of nongonococcal urethritis (N.G.U.) were first recorded separately by clinics in England and Wales, the incidence of the disease has risen steadily. Like gonorrhoea in males, the annual number of cases has doubled in a decade (Table 1 ), but the causal organism remains unknown and treatment suffers thereby from empiricism.

TABLE I

GONORRHOEA AND N.G.U. RATIO, 1951-61

\begin{tabular}{|c|c|c|c|}
\hline Year & Gonorrhoea & N.G.U. & $\begin{array}{c}\text { Ratio } \\
\text { G.C. : N.G.U. }\end{array}$ \\
\hline $\begin{array}{l}1951 \\
1952 \\
1953 \\
1954 \\
1955 \\
1956 \\
1957 \\
1958 \\
1959 \\
1960 \\
* 1961\end{array}$ & $\begin{array}{l}14,975 \\
15,499 \\
15,258 \\
13,958 \\
14,008 \\
12,324 \\
19,615 \\
22,407 \\
24,946 \\
28,308 \\
29,500\end{array}$ & $\begin{array}{l}10,659 \\
11,450 \\
13,095 \\
13,250 \\
14,122 \\
14,756 \\
16,057 \\
13,536 \\
20,229 \\
21,719 \\
24,290\end{array}$ & $\begin{array}{l}1 \cdot 40: 1 \\
1 \cdot 35: 1 \\
1 \cdot 16: 1 \\
1 \cdot 05: 1 \\
1: 1 \cdot 008 \\
1: 1 \cdot 11 \\
1 \cdot 22: 1 \\
1 \cdot 65: 1 \\
1 \cdot 23: 1 \\
1 \cdot 30 \vdots 1 \\
1 \cdot 21: 1\end{array}$ \\
\hline
\end{tabular}

* Completed from quarterly returns to the Ministry of Health for England and Wales.

Gordon (1943) stated that all cases of urethritis were gonococcal in origin. Mast (1948) thought N.G.U. was a new disease. Viewing the subject from a historical standpoint, Harkness (1950) quoted Luys (1922) to the effect that Aretaeus of Cappadocia in the 1st century A.D. had distinguished between spermatorrhoea and pathological discharges and had recognized a thick white discharge from acute cystitis. A host of British clinicians in the last 200 years, including Neale (1756), Brodie (1818), Stevenson (1823), Abernethy (1826), Parker (1839), Carmichael (1842), and Dawson (1848), have all claimed that gonorrhoea was not the sole cause of urethritis. Not till the end of the 19th century, however, was it suggested that a urethral discharge could be abacterial: Guiard (1897) and Barlow (1899)

\footnotetext{
* Received for publication July 21, 1962.
}

found no organism but still considered the condition to be contagious. Waelsch (1904) was the first to describe N.G.U. in detail; he found few organisms in smears and his cultures were mostly sterile.

Since Lindnér (1910) first described elementary bodies in the urethral discharge, various attempts have been made to prove a viral aetiology in N.G.U., but these efforts have so far proved unsuccessful.

Nicol and Edward (1953) and Klieneberger-Nobel (1945) tried to incriminate the pleuropneumonia-like organisms but failed to prove a case.

Willcox (1954) concluded that bacterial urethritis was not common. Wilkinson (1959) pointed out that anaerobic culture studies of N.G.U. have been few; one example is the United States Army study at Camp Kilner, but the results were obtained from a few cases only and differed little from cultures made from controls. Stokes (1958) showed that infective anaerobes occurred in 31.5 per cent. of 220 cultures, and her work prompted a further study of the cause of N.G.U. from the anaerobic standpoint.

Six groups of organisms may be cultured anaerobically (Docum. Geigy (Basel), 1963):

(1) Pleuropneumonia-like organisms (P.P.L.O.).

(2) Veillonella

(3) Neisseria reniformis

(4) Anaerobic Streptococci and Staphylococci
(a) Staph. aerogenes
(b) Gaffkya anaerobia
(c) Strept. equisimilis
(d) Strept. anaerobius
(e) Strept. evolutus
(f) Strept. liqifaciens
(g) Parvo bactericeae

(i) Mima polymorphe

(ii) Herellae vaginicola

(iii) Colloidesanoxydana

(5) Fusiformis

(6) Bacteroides

(7) Leptotrichia 
Fusiformis and Bacteroides are associated with ulcers and abscess formation and were thus excluded from the study on clinical grounds. Leptotrichia is the former name of a genus of bacterial organisms no longer recognized as a genus. It is classified as shown and is excluded as a possible cause of N.G.U.

The causal organism, if an anaerobic bacterium, should therefore, belong to one of the first three groups. The report of an investigation on these lines has been noted (Stokes, 1958), and P.P.L.O. have been excluded from special study as they have been studied elsewhere in detail (vide supra).

Veillonella are Gram-negative cocci and grow readily on ordinary media under anaerobic conditions. They are found in the upper respiratory and alimentary tracts as commensals and doubtful pathogens.

\section{Material}

Of the 81 men studied in the clinics at Sheffield, Barnsley, Doncaster, and Rotherham, 73 were born in the United Kingdom, and eight were coloured immigrants. Their ages ranged from $17 \frac{1}{2}$ to 64 years (average 32.4). 44 were married, or married and separated, and 37 were single or widowed; of the 44 married men, fourteen admitted extramarital exposure. Ten female contacts were also studied.

\section{Method}

Urethral specimens were taken from each patient at the first attendance to exclude $N$. gonorrhoeae and Trichomonas vaginalis. Specimens were also taken on charcoal-impregnated swabs and sent in Stuart's medium for culture of the gonococcus and $T$. vaginalis and for anaerobic incubation for 5 days.

\section{Findings}

98 specimens were examined, 85 cultures from the 81 men and thirteen specimens from the ten females being sent for anaerobic culture. Specimens were taken from the urethra, cervix, and vagina of the ten women.

The findings may be tabulated as follows:

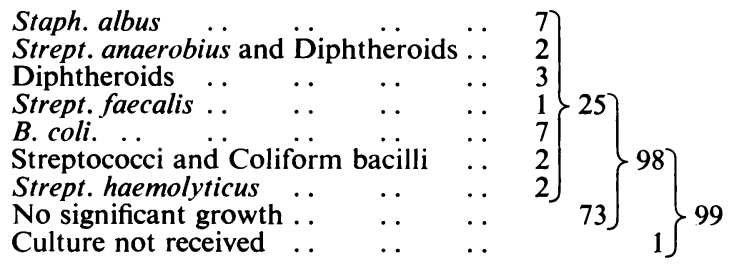

Thus commensals and contaminants were found in 21.7 per cent., and no significant growth in 78.73 per cent. There were no parallel findings in those couples in whose cultures anaerobic growth occurred.

\section{Discussion}

An anaerobic culture of the urethral discharge in 81 cases of N.G.U. did not yield any information regarding a bacterial cause of the disease nor did the study suggest one.

One point of interest was the G.C./N.G.U. ratios. Table II shows how these compare with the findings for England and Wales as a whole for the years 1958-61.

The total of white and coloured patients and the percentage of each is given in Table III.

TABLE II

RATIO OF GONORRHOEA TO N.G.U. IN FOUR YORKSHIRE CLINICS, BY RACE

\begin{tabular}{|c|c|c|c|c|c|c|c|c|c|}
\hline \multirow{2}{*}{ Year } & \multirow{2}{*}{$\underset{\text { Rational }}{\text { Natio }}$} & \multicolumn{2}{|c|}{ Sheffield } & \multicolumn{2}{|c|}{ Rotherham } & \multicolumn{2}{|c|}{ Doncaster } & \multicolumn{2}{|c|}{ Barnsley } \\
\hline & & White & Coloured & White & Coloured & White & Coloured & White & Coloured \\
\hline 1958 & $1 \cdot 65: 1$ & $1: 1 \cdot 45$ & $2 \cdot 42: 1$ & $1: 1 \cdot 50$ & $1: 0.57$ & - & - & $1: 0.52$ & - \\
\hline 1959 & $1 \cdot 23: 1$ & $1: 0.98$ & $3 \cdot 52: 1$ & $1: 1 \cdot 72$ & $1: 0 \cdot 38$ & - & - & $1: 0.28$ & - \\
\hline 1960 & $1 \cdot 30: 1$ & $1: 1 \cdot 08$ & $3 \cdot 36: 1$ & $1: 2 \cdot 20$ & $1: 0.90$ & $1 \cdot 05: 1$ & $2 \cdot 61: 1$ & $1: 0 \cdot 84$ & - \\
\hline 1961 & $1 \cdot 12: 1$ & $1: 1 \cdot 55$ & $4 \cdot 08: 1$ & $1: 1 \cdot 02$ & $1: 0 \cdot 12$ & $0.52: 1$ & $1 \cdot 36: 1$ & $1: 1 \cdot 95$ & - \\
\hline
\end{tabular}

TABLE III

INCIDENCE OF GONORRHOEA AND N.G.U., BY RACE

\begin{tabular}{|c|c|c|c|c|c|c|c|c|c|}
\hline \multirow{2}{*}{\multicolumn{5}{|c|}{ Race }} & \multicolumn{3}{|c|}{ No. of Cases } & \multirow{3}{*}{$\begin{array}{c}\begin{array}{c}\text { N.G.U. as } \\
\text { Percentage of } \\
\text { Total by Race }\end{array} \\
52 \cdot 8 \\
23 \cdot 1\end{array}$} & \multirow{3}{*}{$\begin{array}{c}\text { N.G.U. as } \\
\text { Percentage of } \\
\text { Grand Total } \\
\begin{array}{c}34 \cdot 4 \\
8 \cdot 0\end{array}\end{array}$} \\
\hline & & & & & \multirow{2}{*}{$\begin{array}{c}\text { Gonorrhoea } \\
743 \\
646\end{array}$} & \multirow{2}{*}{$\begin{array}{c}\text { N.G.U. } \\
831 \\
194\end{array}$} & \multirow{2}{*}{$\begin{array}{r}\text { Total } \\
1,574 \\
840\end{array}$} & & \\
\hline $\begin{array}{l}\text { White . } \\
\text { Coloured }\end{array}$ & $\cdots$ & $\begin{array}{l}\cdots \\
\cdots\end{array}$ & $\begin{array}{l}\cdots \\
\cdots\end{array}$ & $\begin{array}{l}\cdots \\
\cdots\end{array}$ & & & & & \\
\hline Total .. & . & $\ldots$ & $\ldots$ & $\ldots$ & 1,389 & 1,025 & 2,414 & - & - \\
\hline
\end{tabular}


The higher incidence of the disease in men born in the United Kingdom is noteworthy, though it may be that the more promiscuous coloured patient is running a greater risk of contracting gonorrhoea when there is a higher incidence of this disease.

\section{Summary}

(1) 98 specimens, 85 of them from 81 males with non-gonococcal urethritis and thirteen from ten female consorts were cultured anaerobically for 5 days: $78 \cdot 73$ per cent. showed no significant growth, and in $21 \cdot 27$ per cent. commensal contaminant organisms were grown.

(2) There was no correlation between the cultures taken from the consorts.

(3) N.G.U. was more than twice as common among white patients $(52.7$ per cent.) as among coloured men ( 23.09 per cent).

(4) An anaerobic organism was not found to be a factor in, or a cause of, N.G.U.

(5) Further investigation of the origin of this condition is indicated.

I thank Dr. R. S. Morton, Consultant Venereologist, for his help in preparing this paper, and Dr. A. L. Hilton, who suggested this line of investigation and supplied details of patients in his care at the Rotherham and Doncaster clinics. Dr. H. Lederer carried out the cultural investigation at Doncaster, and Dr. A. L. Little, County Laboratories, Wakefield, the investigations for Sheffield and Barnsley.

\section{REFERENCES}

Abernethy, J. (1826). "Surgical Observations on Diseases resembling Syphilis and on Disease of the Urethra", 5th ed., p. 5. London (Cited by Harkness, 1950).

Barlow, R. (1899). Dtsch. Arch. klin. Med., 66, 444.

Brodie, B. C. (1818). "Pathological and Surgical Observations on Diseases of the Joints", p. 54. Longman, Hurst, Rees, Orme, and Brown, London.

Carmichael, E. (1842). "Clinical Lectures on Venereal Diseases", Dublin (Cited by Harkness, 1950).

Dawson, R. (1948). "An Essay on Spermatorrhoea, and Urinary Deposits", 4th ed. Hughes, London.

Docum. Geigy (Basel) (1953). pp. 129-178.

Gordon, J. E. Quoted by Harkness (1950), p. 7.

Guiard, F. P. (1897). Ann. Mal. Org. gén.-urin., 15, 449.

Harkness, A. H. (1950). "Non-Gonococcal Urethritis". Livingstone, Edinburgh.

Klieneberger-Nobel, E. (1945). Lancet, 2, 46.

Lindnér, K. (1910). Wien. klin. Wschr., 23, 283.
Luys, G. (1922). “A Text-book on Gonorrhoea and its Complications", trans. A. Foerster, 3rd ed., p. 2. Baillière, Tindall and Cox, London.

Mast, G. W. (1948). Amer. J. Syph., 32, 106.

Neale, T. (1756). "A Practical Treatise on the Venereal Disease, and the Art of Bleeding", p. 38. Robinson, London.

Nicol, C. S., and Edward, D. G. ff. (1953). Brit. J. vener. Dis., 29, 141.

Parker, L. (1839). "The Modern Treatment of Syphilitic Diseases". Churchill, London.

Stevenson, J. (1823). "A Simplified Practical Guide to the Cure of Venereal Complaints", p. 9, Hill, London.

Stokes, E. J. (1958). Lancet, 1, 668.

Waelsch, L. (1904). Arch. Derm. Syph., Wien., 70, 103.

Willcox, R. R. (1954). Brit. med. J., 1, 13.

Wilkinson, A. E. (1959). Personal communication.

\section{ADDITIONAL BIBLIOGRAPHY}

Bridré, J., and Donatien, A. (1923). C.R. Acad. Sci. Paris, 177, 841.

-, (1925). Ann. Inst. Pasteur., 39, 925.

Csonka, G. W., and Furness, G. (1960). Brit. J. vener. Dis., 36, 181 .

Edward, D. G. ff. (1952). Ibid., 28, 89.

Grimble, A., and Csonka, G. W. (1955). Ibid., 31, 228.

Harkness, A. H., and Henderson-Begg, A. (1948). Ibid., 24,50 .

Klieneberger, E. (1955). J. Path. Bact., 40, 93.

Lejman, K., and Bogdaszewska-Czabanowska, J. (1961) Brit. J. vener. Dis., 37, 164.

Mackie, T. J., and McCartney, J. E. (1953). "Handbook of Practical Bacteriology", 9th ed. Livingston, Edinburgh.

Nocard, E., and Roux, P. (1898). Ann. Inst. Pasteur., 12. 240.

Parrino, P. S. (1954). U.S. armed Forces med. J., 5, 1249.

Stokes, E. J. (1955). Lancet, 1, 276.

Wilson, G. S., and Miles, A. A. (1955). "Topley and Wilson's Principles of Bacteriology and Immunity", 4th ed. Arnold, London.

Turner, A. W. (1935). J. Path. Bact., 41, 1.

La culture anaérobique dans le diagnostic de l'urétrite non-gonococcique

\section{RÉSUMÉ}

(1) 98 sérums, 85 tirés de 81 hommes atteints d'urétrite non-gonococcique, et 13 tirés de 10 de leurs partenaires sexuelles, furent cultivés hors de l'air pendant 5 jours; $78,73 \%$ ne montrèrent aucune croissance et des organismes commensaux furent cultivés dans $21,27 \%$.

(2) Il n'y avait aucune correspondance entre les cultures des hommes et des femmes.

(3) L'urétrite non-gonococcique fut plus de deux fois plus commune parmi les malades blancs $(52,7 \%)$ que parmi ceux de couleur $(23,09 \%)$.

(4) On ne trouva aucun organisme anaérobique qui pouvait être associé à l'urétrite non-gonococcique ou qui pouvait la causer.

(5) Il faut approfondir nos études de l'origine de cette maladie. 